\title{
Editorial
}

\section{Controlling the leisure asset base: From finance to land-use planning}

One recurrent theme that occurs in the Editorial column for this Journal is the need for leisure operators and all those involved in the leisure property industry to be flexible and accommodate change; indeed, it sometimes seems as though change is the only constant.

At the time of the publication of this issue, however, it is not just the industry that is a mirror of societal change. This time it is the financial context to leisure property that is seemingly undergoing fundamental change. The world stock markets have taken yet another steep fall, with corporate values in many countries now running at levels prevailing some five or more years ago. What was considered to be a (hopefully) transient drop in world share prices last year consequent on 11th September has proven to be a very serious and ongoing issue bound up with very deep-seated concerns that affect all aspects of the economy, but especially the corporate sector.

Starting with the collapse of Enron, which rocked financial advisers throughout the world, the news has been crowded with allegations of financial cover-ups and corporate collapse, prompting even presidential intervention to try and revive some confidence. While the headline news has not focused on leisure companies, the shockwaves will undoubtedly be felt throughout the leisure and property industries. Early indications are that the flight from equities might be good news for property as investors seek solace in 'bricks and mortar', 'but leisure developers are reported to be in reflective mood as the concentration shifts towards home markets and levels of projected investment are cautious judged by the levels achieved in recent years. ${ }^{2}$ It is perhaps salutary to note that earlier this year, Will Hutton, a widely respected economist and political commentator, reported a 'growing consensus among economists that the current American economic downturn will be short-lived.' Few might agree with such an analysis today, due in no small measure to a loss of confidence in the integrity of corporate financial control procedures.

\section{THE NEED FOR MANAGEMENT AND FINANCIAL ANALYSIS}

Given this context of negligence and even fraud within the financial control and monitoring of companies, it is very appropriate that two papers in the current issue, while written prior to the record falls in share prices recorded this month, provide timely reminders 
to all operators and analysts of the need to be aware of fundamental management and accounting issues.

Singh and Schmidgall provide a fascinating insight into just how vexed the area of financial analysis is and how varied the relative importance placed on available ratios and analytical tools by different managers and accountants involved in leisure asset management. While their study concentrates on the analysis carried out by operators and financial controllers of US hotels and lodging houses, the principles of astute and reflective analysis that they espouse could equally apply to a range of other businesses, both inside and outside the leisure industries.

There are two particular findings that resonate and raise concerns for the industry. The first is that most of those surveyed take greatest note of operating ratios and place comparatively low priority on evaluating the specific balance sheet ratios. They point out that many of those surveyed showed little knowledge of solvency and asset/ liability ratios. Without such knowledge, as the authors point out, it is difficult, if not impossible, for operators to be confident that they will be able to meet their long-term debt obligations.

The second point of particular note that they record is a lack of professional certification among financial controllers. While the figures that they report are historic, the implications from their conclusions are that in their survey they did not pick up signs of change.

These two issues together - a lack of education and a concentration on the operating account at the expense of consideration of the balance sheet - are very timely. And the issues are not ones that affect the USA only. Concerns about the failure of internal and external auditing processes to pick up on lack of financial management rigour are of importance on both sides of the Atlantic, with concerns that other such failures could occur being a very important driver of the stock market collapses.

This in itself raises another issue. The development of international accounting standards has provided a framework from which to develop common property valuation standards and accounting reporting practices. However, there are still many very significant differences in the way that property assets are treated in the accounts in different countries. For example, the ability to revalue on a regular basis is not universal and in some countries is not allowed; also the bases on which valuations of operational assets are conducted are inconsistent, with some countries utilising the market value approach while others adopt a value to the business. At the time of writing, within the UK there is much debate as to the most appropriate basis on which to value operational assets within the balance sheet. The RICS is currently in the process of developing new practice statements but these still include the value to the business (or existing use value), a concept that is not accepted by the International Valuation Standards Committee. $^{4}$ 
Thus while the call to operators and their financial executives to adopt a rigorous and more wide-ranging set of analytical tools is well made by Singh and Schmidgall, the needs of the investment and funding community will only be met when there is also a common set of account and valuation principles on which to base the financial analysis. And until these needs are met, there is likely to be a lack of confidence in corporate financial reporting. The difficulty is that while professionals may agree on the need for change, obtaining consensus as to the nature of that change is always problematic. Further, the implementation of change may have consequences that are hard to forecast. For example, few in the UK really foresaw that changes to accounting regulations could have such a profound affect on the operation of the pensions industry - and with it the property investment markets. ${ }^{5}$

In his paper Skripsky reinforces some of the same messages. While his focus is on the need for good operational plans, owned and developed by the entire team, the message is unequivocal. Successful businesses are well planned operationally and financially and the plan should be used as a measurement of performance. However, he stops short of describing the ways in which that measurement should be detailed. This is an area that could usefully be developed in later papers.

\section{FROM MICRO TO MACRO ISSUES: LAND-USE PRESSURES AND A NEED FOR INCREMENTAL CHANGE}

If the papers by Skripsky and Singh and Schmidgall could be regarded as dealing with micro issues relating to effective management of leisure property assets, the remaining papers pick up on more macro concerns relating to the nature of leisure and its relationship with land-use planning.

Randall Upchurch's paper on the development of the timeshare market and its evolution into a vacation ownership industry picks up the recurrent theme of changing product and reinforces the mission of this Journal: to track and reflect the growth in the leisure property industry. In his paper Upchurch refers to the 'leisure product continuum', which is a very apt description of the spectrum of holiday accommodation from overnight tourism lodgings in which a service is purchased to the full vacation holiday home in which a full property interest is acquired. In detailing the development of timeshares, he outlines the shift to quality - a phenomenon that has been noted in other leisure sectors (for example the transformation of the utilitarian single-screen cinema to the luxury multiplex) — and predicts that this trend will continue.

If he is right in this prediction, it is almost inevitable that, as developers seek appropriate locations which offer both tranquility and accessibility, they will come into conflict with state land-use control regulations, in which those responsible seek to balance the needs of all stakeholder groups. The conflicts that can arise in land- 
use planning terms within the UK provide the subject material for two further papers.

In the UK, the current system of land-use planning is under review, as it is regarded as cumbersome, inflexible and out of date. ${ }^{6}$ This, the government argues, has led to the planning system being unresponsive to the changing needs of society. In no aspect is this clearer than in relation to leisure land-use planning, a point developed in the paper by Sayce and McIntosh. It details the findings of research carried out last year on behalf of the Leisure Property Forum ${ }^{7}$ and reports support for a far more integrated approach to the treatment of leisure. Under current rules, there is lack of clarity as to the distinction between leisure and retail premises and little rationale for current regulations surrounding the ability to change the use of a property without express consent. One of the areas explored in the paper is the suggestion that leisure uses be grouped - for example into an 'urban entertainment' class - to recognise better the emergence of a range of mixed-use developments. Given the important role that leisure property now plays within town and city centres, the use of a classification system dating back some 15 years is clearly deplorably out of date. The paper supports the notion of flexibility while recognising that the less prescriptive the system of controls adopted, the more open to political pressure the system potentially becomes.

The pressure on planning systems as each stakeholder group endeavours to be heard is a key concern in Powell's robust paper on the planning situation in Westminster, London. This is an area that has been very much under planning pressure due to the strength of its brand image as a centre for entertainment, which he argues has long been unrivalled. However, recent changes in entertainment trends have brought stakeholders into conflict as a result of rapid growth in entertainment venues - often creating noisy environments unacceptable to residents. In his paper, Powell advocates the critical importance of developing a partnership approach to ensure that a right balance can be struck between business entertainment and leisure uses.

The message of the need to work together to provide appropriate solutions to urban problems is one that is explored by Kooijman in his detailed exploration of the relationship between leisure, urban entertainment and retailing within the city centre. Arguing that the concept of putting leisure and retailing together is in the Netherlands not a new idea, he sees very clearly the requirement to be sensitive to the needs of maintaining and enhancing the city centre.

This point is well made. Across the world, increased urbanisation is taking place, and with these increased population densities the need to contain conflicts by appropriate consultative processes will gain in importance. Beauregard and Haila argue that "people and institutions have invested dearly in the city as it is. The value of their investments depends on relationships continuing relatively 
unchanged. ${ }^{8}$ However, relativity is in the eye of the beholder - or stakeholder - and perhaps their analysis underplays the need both to recognise and to accommodate incremental change. In this, successful integration of leisure within the urban land-use mix is a key component.

Sarah L. Sayce July 2002

\section{References}

1 In June 2002, the UK's FTSE Real Estate Index outperformed the FTSE's All-share Index for the first time in eight years (reported in Property Week, 14th June)

2. Ernst \& Young (2002) European Tourısm and Leisure Development Survey

3. Hutton, W. (2002) The World We're In, Little, Brown, London, p. 355.

4. For a discussion on these issues, see the RICS website (www.rics.org) for details of the interpretation of existing use value; see also the work of the International Valuation Standards Committee

5. DTZ Research (2002) 'Money into Property', DTZ Research, London. This report estumates that in the UK in 2001 pension fund net investment in property dropped to $£ 15 \mathrm{~m}$ from a level of some $£ 1.7 \mathrm{bn}$ the year before. While this was for a number of complex reasons, accounting standard changes were a very significant driver.

6. Department of Transport, Local Government and the Regions (2001) Planning Delivering a Fundamental Change, DTLR, London

7. Leisure Property Forum, Kingston University, Kıng Sturge and Denton Wilde Sapte (2001) Leisure Property and the Use Classes Order Are They Still Approprate?, LPF. London.

8. Beauregard, R. A. and Haila, A. (2000) 'The unavoldable contınuties of the city', in Marceuse, P and van Kempen, R. (eds) Globalizing Cittes A New Spatial Order. Blackwell, Oxford, pp 22-36 